\title{
The Effects of Topic Interest and L2 Proficiency on Writing Skill among Iranian EFL Learners
}

\author{
Rasool Mirshekaran \\ Department of English, Faculty of Humanities, Chabahar Maritime University, Chabahar, Sistan va Baluchestan, Iran \\ Ehsan Namaziandost \\ Department of English, Faculty of Humanities, Shahrekord Branch, Islamic Azad University, Shahrekord, Iran
}

\author{
Mojtaba Nazari \\ Department of Linguistics, Faculty of Letters and Humanitis, Shiraz University, Shiraz, Iran
}

\begin{abstract}
This study investigated the effect of topic interest and 12 proficiency on Iranian EFL learners' writing skill. To fulfil this objective, 60 (30 pre-intermediate and 30 intermediate) learners from two high schools in Zarindasht, Fars, Iran were selected based on administering an Oxford Quick Placement Test. The selected participants were then non-randomly divided into two equal experimental groups; namely PreIntermediate High-Interest Topics group (PHIT group) and Intermediate Low-Interest Topics group (ILIT group). After that, the topic interest questionnaire was given to the students to assess their interest level in each topic. When the students' level of interest was specified, the PHIT group received five high-interest topics and five low-interest topics were given to the ILIT group. Then, the researcher measured the participants' English writing skill by administering a researcher-made writing pre-test. In both groups' classroom, the interested topics were taught to learners in 12 sessions and learners wrote on each topic. After the instruction, a writing post-test was administered to the both groups and finally the data were analyzed by using paired and independent samples t-tests. The obtained results indicated that there was a significant difference between the post-tests of PHIT and ILIT groups. The findings indicated that the PHIT group significantly outperformed the ILIT group $(p<.05)$ on the post-test. The implications of this study can make the teachers aware that topic interest plays an important role in improving writing skill.
\end{abstract}

Index Terms-interest, topic interest, writing skill, Iranian EFL learners

\section{INTRODUCTION}

Learning a second language includes the involvement of four pivotal skills; listening speaking, reading, and writing. Writing is a definitive and final ability that students should learn. It is an essential communication skill that cannot be gained; it can be socially transmitted or can be learned through formal direction. Among the four skills of language, writing and speaking are productive skills (Bristow Evans, 2018). Of course, there are notable differences between them. All normal people learn to speak while writing should be instructed to them. In contrast with talking, composing forces more noteworthy requests on the students since there is no quick criticism in composed collaboration. The writer needs to prognosticate the reader's interaction and create a text which comport to Grice's (1975) cooperative principle. Based on this principle, the writer should attempt to compose a reasonable, important, honest, useful, fascinating, and paramount content. The reader, then again, expounds the text regarding the writer's assumed purpose if the essential pieces of information are accessible in the content. Phonetic exactness, lucidity of introduction, and association of thoughts are on the whole basic in the adequacy of the informative demonstration, since they give the essential pieces of information to understanding.

Considering the fact that the objective of writing teaching is urge students to impart adequately, through writing, it is of significance to discover why a few students are reluctant to get associated with composing exercises in the classrooms. Such unwillingness, which may be credited to their discernments and demeanors, as a rule influences student to lose their enthusiasm for writing. Gradually, they would conclude that they are not able to make any development in their writing classes. The problem is earnest in an English as a Foreign Language (EFL) setting where there is little introduction to the objective language outside the classroom. In accordance with the hypothesis of contemplated activity, investigation in instruction proposes that learner discernments and states of mind toward a subject result to scholarly achievement (Popham, 2005; Royster, Kimharris, \& Schoeps, 1999). Therefore, appropriate consideration should be paid to the impact of learners' cognitions and attitudes toward their classroom writing.

To date, rare studies have been done on investigating the nature of the interaction between the factors of topic interest and L2 proficiency on writing improvement. Moreover, the existent study on the different components listed above has mostly been carried out with adult writer participants, including writing enhancement as the consequence variable of interest (e.g. Carrell \& Wise, 1998). Yet numerous L2 students in educational settings are children and adolescents. The 
addendum part emphasizes the pertinent discoveries in the extant literature on L1 and L2 reading comprehension, writing development and vocabulary acquisition and identifies the existent gaps and impediments, which legitimize the present examination trying to reveal new insight into student inclusion in L2 writing process.

\section{A. Objectives and Significance of the Study}

This study follows two crucial aims; the first one is investigating the effects of topic interest on improving Iranian EFL learners' writing improvement. The second one is inspecting if L2 language proficiency has any effect on enhancing writing skill.

This study provides some implications for language educators in simplifying L2 writing process. The important positive effect of topic interest on L2 writing ability for learners of all proficiency levels supports teachers' and material developers' endeavors to equip the students' selective topics to increase their writing ability. The students can maximize their vocabulary knowledge unintentionally through writing texts. Findings from this investigation can ensure L2 writing specialists as well as educators that one source of L2 writing troubles is the lack of interest to topics. Given the proper pattern and most loved themes, writers may be able to perceive texts and dominate their inadequately improved linguistic information.

\section{B. Research Questions and Hypotheses}

\section{The present study was designed to find answer to the following questions:}

RQ 1. Does topic interest have any significant impact on Iranian EFL learners' writing skill?

RQ 2. Does L2 proficiency significantly impact Iranian EFL learners' writing skill?

\section{The following null hypotheses were tested:}

HO 1. Topic interest does not have any significant impact on Iranian EFL learners' writing skill.

H0 2. L2 proficiency does not significantly impact Iranian EFL learners' writing skill.

\section{REVIEW OF THE LITERATURE}

\section{A. The Impact of Topic Interest, Reading Proficiency, and Gender on L1 Reading Comprehension}

Previous studies on L1 reading has shown that different parts of the reading procedure were significantly facilitated through topic interest. For example, Ainley, Hidi, and Berndorff (2002) operationalized the mental procedures that interceded interest and learning and, through basic condition demonstrating, they detailed that topic interest affirmatively impacted students' affect, which expanded the level of learners' determination, the next straightforwardly affecting reading comprehension.

L1 research has likewise demonstrated that topic interest communicates with other student factors, for example, reading proficiency, verbal capacity, and gender. For instance, early examination by Walker, Noland, and Greenshields (1979) explored the joined impacts of L1 reading capacity and topic enthusiasm on reading understanding. The investigation detailed noteworthy impacts of theme enthusiasm on reading comprehension in that members better understand sections portraying more intriguing points than those delineating less fascinating subjects. Furthermore, contrasts in perception over the fluctuating topic interest conditions were more noticeable in less capable readers than in more capable readers. However, an examination by Stevens (1980) revealed that more capable readers perceive more from the more intriguing texts than less fascinating ones, however no distinctions in understanding because of topic interest were acquired for less capable readers.

More recently, in an examination on L1 perusing perception evaluation, Bray and Barron (2004) explored the connections between topic interest, verbal capacity, and another applicable reader- based factor (i.e. sexual orientation). Their outcomes uncovered a reliably solid positive connection between verbal capacity and reading comprehension for all members paying little respect to their level of enthusiasm for the reading materials. What's more, they revealed better perception by young ladies contrasted with young men, and a more grounded positive connection between interest level and appreciation for young ladies contrasted with young men. In other words, topic interest affected girls' performance more than boys' performance. Yet, different examinations considering the double impacts of sexual orientation and theme enthusiasm on L1 perusing cognizance got diverse outcomes (Ainley, Hillman, \& Hidi, 2002; Walker et al., 1979), whereby perception was fundamentally influenced by subject intrigue, yet just for young men. In these examinations, young men scored altogether higher on high-intrigue writings contrasted with low-intrigue writings, though young ladies' understanding execution stayed steady paying little heed to their level of enthusiasm for the topics. Ainley, Hillman, et al. (2002) additionally showed the component of the impacts noted above utilizing a PC program to analyze the connections between sex, topic interest, and comprehension. This examination acquired a 'dynamic evaluation' (p. 417) of topic enthusiasm by not only chronicle intrigue levels through a Likert-type scale, yet by likewise recording students' online full of feeling reactions to entries (i.e. selection of emotions to speak to sentiments evoked by a content), constancy in reading (i.e. choices to keep reading, time spent reading, and number of entry areas read). Comprehension was additionally evaluated on the web. Through way investigations, they presumed that the level of topic interest was essentially connected with full of feeling reactions to writings, which added to the level of industriousness in reading, the last being corresponded with perception. Apportioning the higher-from the lowerinterest messages, the specialists additionally detailed an immediate impact of sexual orientation on topic interest and 
determination, whereby just the girls persevered with less fascinating writings. This examination features the instrument by which topic interest may differentially influence reading understanding in light of different elements, for example, sex.

Generally, the L1 literature done mainly with children and adolescents has administered sturdy impacts of interest on reading comprehension as well as remarkable interactions with gender and reading or verbal capability. The L1 research results are important because this research is additionally concerned with grade school students' writing skill.

\section{B. The Impacts of Topic Interest, Reading Proficiency, and Gender on L2 Reading Comprehension}

L2 reading research has generally centered on post-pubescent and adolescents and has been less fruitful in acquiring critical impacts of topic interest and sexual orientation on reading understanding. For example, Carrell and Wise (1998) and Joh (2006) found no noteworthy impacts of topic interest on their measures of L2 reading comprehension. Nonetheless, there were methodological confinements to these examinations. For instance, Carrell and Wise's estimation of interest had flawed legitimacy in that students rank requested their enthusiasm for 10 reference bookbased themes, paying little respect to their genuine interest for every subject. In spite of the fact that this measure may have shown learners' enthusiasm for the given topics with respect to others, it didn't mirror their total enthusiasm for every subject. Carrell and Wise found no huge primary impact of sex on reading comprehension in their examination, supporting reports by Young and Oxford (1997) and Brantmeier (2003). Interestingly, Young and Oxford found that females more regularly than guys utilized local techniques, for example, lexical inferencing to determine the importance of new words. Subsequently, it is conceivable that there are differential impacts of topic enthusiasm on L2 reading comprehension in light of the sexual orientation of the readers.

However, in independent examinations, LeLoup (1993) and Erçetin (2010) got huge impacts of topic interest on L2 reading comprehension. These examinations exhibited that students reviewed fundamentally more data from highintrigue passages contrasted with low-intrigue passages. LeLoup (1993) additionally discovered huge impacts for the factors of L2 capacity and sex (females reviewed more data than guys). Through regression modeling, LeLoup's examination ascribed most of the watched fluctuation in L2 reading comprehension to the variable of L2 capacity $(28 \%-41 \%)$, trailed by topic interest $(9 \%)$, and sexual orientation $(6 \%)$. LeLoup inferred that females might be more encouraged by high-intrigue topics than guys, and that guys might be more prevented when reading low-intrigue subjects contrasted with females.

\section{Empirical Studies}

Ebrahimi and Javanbakht (2015) examined the impact of topic interest on Iranian EFL learners' reading comprehension ability. With a specific end goal to achieve this point, an experimental method was intended for data collection. Ten EFL students were arbitrarily chosen keeping in mind the end goal to discover how much the students are occupied with reading texts. They answered an interest survey which was designed for this objective. Based on students' responses regarding their interests in reading texts, three most interested topics were given to the control group and three least interested topics were given to the experimental group. The reading texts were taught to learners in three sessions and learners answered their comprehension questions. The students' scores were gathered and submitted for data analysis. The consequence of t-test demonstrated that there is a significant difference between experimental and control group in their performance on reading comprehension texts.

Lee and Pulido (2016) examined the impact of topic interest, as well as L2 proficiency and gender, on L2 vocabulary acquisition through reading. A repeated-measures design was utilized with 135 Korean EFL students. Participants read both high- and low-interest topic passages and took vocabulary posttests (word-form recognition, translation recognition, and translation production) immediately and four weeks after reading. Analyses indicated significant impacts of topic interest and L2 proficiency, and a significant interaction between topic interest and gender. These outcomes were maintained over time. The article deduces by discussing the reinforcing role of topic interest, developing on the motivational factor considered in the involvement load hypothesis.

\section{METHOD}

\section{A. Participants}

The participants of this study were 60 (30 pre-intermediate and 30 intermediate) language learners who were selected among 90 junior high school students at two high schools in Zarindasht, Fars, Iran based on Oxford Quick Placement Test. Their level of English language proficiency was determined on the basis of their scores on the Oxford Quick Placement Test (OQPT). The participants' age range was 14 to 18 . Only males were participated in the current study. They have been studying English as a foreign language for at least three years. The learners were randomly divided into two experimental groups (Pre-Intermediate High-Interest Topics group (PHIT group) and Intermediate Low-Interest Topics group (ILIT group)). There were 30 participants in each group.

\section{B. Instrumentation}

The first instrument is a proficiency test, Key English Test (KET), which was given to the students to measure their English language proficiency. KET examinations reflect a view of language proficiency in terms of a language user's 
overall communicative ability; at the same time, for the purposes of practical language assessment, the notion of overall ability is subdivided into different skills and sub-skills. Four main skills of reading, writing, listening and speaking are recognized, and each of these is assessed within the three test papers (Ramshaw, 2010). This test determined whether the participants are at high; intermediate; or low level.

The second instrument was a topic interest inventory consisting of a 5-items questionnaire was used to assess learners' level of interest in the passage topics. Students were instructed to rate their level of interest in each topic on a scale of 1 ('not interesting') to 7 ('very interesting'). Some reading topics were included in this questionnaire and participants were wanted to rate their level of interest in each topic. Four of them were selected- two highest interest and two lowest interest. The topics were chosen from those which students like the most such as sport, fashion, cosmetic, cooking, and plastic surgery. These topics were selected with the help of supervisor.

The third and the most important instrument for gathering the needed data to reply the research question was a researcher-made writing pre-test. It was based on the students' course book. It included two topics which the students were required to write about one of them arbitrarily. The researcher asked the participants to write a composition on a selected topic. The respondents should write a composition with at least 100-150 words. The pre-test was administered in the class under the supervision of the researcher so as to make sure that the students do it by themselves. After writing about the topic, all the compositions were collected and graded by two English teachers according to the same criteria. The raters considered the students' grammatical correctness, the meaningful of the sentences and the length of each composition while measuring the students' writing skill. The students' errors in (grammatical correctness, the meaningful of the sentences and the length of each composition) were counted and then scored. The validity of the pretest was confirmed by two English experts and its reliability was computed through using inter-rater reliability by means of Pearson correlation analysis and it was $0.817(\mathrm{r}=0.817)$.

Finally, a researcher-made writing post-test was used in the present study. The post-test was based on the topics which were taught to the groups. The post-test included two topics and the students should write about one of them. Two raters rated the students' compositions. The post-test was run to measure the impact of the treatment on the participants' writing improvement. It should be noted that the validity of the post-test was confirmed by two those English experts who validated the pre-test and its reliability was calculated through using inter-rater reliability by means of Pearson correlation analysis and it was $0.986(\mathrm{r}=0.956)$.

\section{Data Collection Procedures}

To conduct the present study, the researcher administrated the OQPT to 90 Iranian junior high school students to determine their level of English proficiency. The researcher selected 60 intermediate and pre-intermediate students and randomly divided them into two experimental groups (PHIT group and ILIT group). After that, the topic interest questionnaire was given to the students to assess their interest level in each topic. When the students' level of interest was determined, five high-interest topics were given to the PHIT group and five low-interest topics were given to the ILIT group. Then they were pretested through the researcher-made writing pre-test. Before writing on the topic, the teacher used prewriting activities including brainstorming technique to collect the students' ideas and information about the topic. This was done to activate and prepare the students to write. In each session, one topic was given to the students to write a composition about it. Their compositions were collected and graded at the end of each session. This procedure continued to teach all the topics. After teaching all the topics, a writing post-test based on high-interest topics was given to the experimental group and a writing post-test based on low-interest topics was given to the control group. Finally, the data were analyzed by following the next section.

\section{Data Analysis Procedures}

In order to answer the research question, data analysis was carried out by using SPSS software version 25. Firstly, Kolmogorov-Smirnov (K-S) test was used to check the normality of the gathered data. Secondly, descriptive statistics including means and standard deviation were computed. Thirdly, to examine the impacts of 12 proficiency and topic interest on Iranian EFL learners' writing skill, independent and paired samples t-tests were run.

\section{RESULTS}

At first in order to find out whether the gathered data were normally distributed, One-Sample Kolmogorov-Smirnov test was run on all scores of pre and post-test. 
TABLE 1.

ONE-SAMPLE KOLMOGOROV-SMIRNOV TEST (GROUPS' PRE AND POST-TESTS)

\begin{tabular}{|c|c|c|c|}
\hline & \multicolumn{3}{|c|}{ Kolmogorov-Smirnov $^{\mathrm{a}}$} \\
\hline & Statistic & df & Sig. \\
\hline PHIT Group Pretest & .148 & 30 & .091 \\
\hline PHIT Group Posttest & .152 & 30 & .076 \\
\hline ILIT Group Pretest & .137 & 30 & .158 \\
\hline ILIT Group Posttest & .128 & 30 & $.200^{*}$ \\
\hline
\end{tabular}

Table 1 shows that the scores of both groups in pre and post-test were normally distributed, that is the Asymp significance level was less than the observed value $(.091, .076, .158, .200>.05)$, and accordingly the criteria for running parametric statistics like $t$-test were met. Descriptive statistics of the pre-test of both groups is shown in Table 2.

TABLE 2.

GROUP STATISTICS (PRE-TEST OF BOTH GROUPS)

\begin{tabular}{llllll}
\hline \multirow{5}{*}{ Pretest } & Groups & $\mathrm{N}$ & Mean & Std. Deviation & Std. Error Mean \\
& PHIT group & 30 & 18.0667 & 1.43679 & .26232 \\
\cline { 2 - 6 } & ILIT group & 30 & 17.5333 & 1.71672 & .31343 \\
\hline
\end{tabular}

Table 2 shows the performance of both PHIT group and ILIT group in the pre-test. The mean score of the ILIT group $(M=17.5333)$ was greater than the mean score of the PHIT group $(M=18.0667)$. This difference does not seem to be a significant one, but to ascertain whether it is or not, Independent Samples $t$-test is run in Table 3.

TABLE 3.

INDEPENDENT SAMPLES T-TEST (PRE-TEST OF BOTH GROUPS)

\begin{tabular}{|c|c|c|c|c|c|c|c|c|c|c|}
\hline & & \multicolumn{2}{|c|}{$\begin{array}{l}\text { Levene's Test for } \\
\text { Equality of } \\
\text { Variances }\end{array}$} & \multicolumn{7}{|c|}{ t-test for Equality of Means } \\
\hline & & \multirow[t]{2}{*}{$\mathrm{F}$} & \multirow[t]{2}{*}{ Sig. } & \multirow[t]{2}{*}{$\mathrm{t}$} & \multirow[t]{2}{*}{ df } & \multirow[t]{2}{*}{$\begin{array}{l}\text { Sig. (2- } \\
\text { tailed) }\end{array}$} & \multirow[t]{2}{*}{$\begin{array}{l}\text { Mean } \\
\text { Differen } \\
\text { ce }\end{array}$} & \multirow[t]{2}{*}{$\begin{array}{l}\text { Std. Error } \\
\text { Difference }\end{array}$} & \multicolumn{2}{|c|}{$\begin{array}{l}95 \% \text { Confidence } \\
\text { Interval of the } \\
\text { Difference }\end{array}$} \\
\hline & & & & & & & & & Lower & Upper \\
\hline \multirow[t]{2}{*}{$\begin{array}{l}\text { Pretes } \\
\mathrm{t}\end{array}$} & $\begin{array}{l}\text { Equal } \\
\text { variances } \\
\text { assumed }\end{array}$ & 2.154 & .148 & 1.305 & 58 & .197 & .533 & .408 & -.284 & 1.351 \\
\hline & $\begin{array}{l}\text { Equal } \\
\text { variances not } \\
\text { assumed }\end{array}$ & & & 1.305 & 56.25 & .197 & .533 & .408 & -.285 & 1.352 \\
\hline
\end{tabular}

Table 3 shows that since the Sig. (2-tailed) value is greater than the alpha level $(.05<.197)$, it could be argued that there was not a statistically significant difference between the pre-test scores of the learners in the PHIT group $(M=$ $18.0667, S D=1.43679)$ and the participants in ILIT group $(M=17.5333, S D=1.71672)$. Therefore, it was concluded that the difference between the two groups was insignificant at the beginning of the treatment. After the treatment was done, the participants in both groups sat for writing post-test. Table 4 shows the descriptive statistics related to these analyses.

TABLE 4.

\begin{tabular}{llllll}
\multicolumn{6}{c}{ GROuP STATISTICS (POST-TEST OF BOTH GROUPS) } \\
\hline \multirow{2}{*}{ Posttest } & Groups & $\mathrm{N}$ & Mean & Std. Deviation & Std. Error Mean \\
\cline { 2 - 6 } & PHIT group & 30 & 25.4667 & 1.54771 & .28257 \\
\cline { 2 - 6 } & ILIT group & 30 & 18.7333 & 2.08332 & .38036 \\
\hline
\end{tabular}

On the post-test, the mean score of the PHIT group $(M=25.4667)$ was more than the mean score of the ILIT group $(M=18.7333)$. To check the statistical (in-) significance of these differences between the post-test scores of the two groups in their post-test scores, one needs to consult the Sig. (2-tailed) column in the $t$ test table which follows.

TABLE 5.

INDEPENDENT SAMPLES T-TEST (POST-TEST OF BOTH GROUPS)

\begin{tabular}{|c|c|c|c|c|c|c|c|c|c|c|}
\hline & & \multicolumn{2}{|c|}{$\begin{array}{l}\text { Levene's Test for } \\
\text { Equality of Variances }\end{array}$} & \multicolumn{7}{|c|}{ t-test for Equality of Means } \\
\hline & & \multirow[t]{2}{*}{$\mathrm{F}$} & \multirow[t]{2}{*}{ Sig. } & \multirow[t]{2}{*}{$\mathrm{t}$} & \multirow[t]{2}{*}{ df } & \multirow[t]{2}{*}{$\begin{array}{l}\text { Sig. (2- } \\
\text { tailed) }\end{array}$} & \multirow[t]{2}{*}{$\begin{array}{l}\text { Mean } \\
\text { Difference }\end{array}$} & \multirow[t]{2}{*}{$\begin{array}{l}\text { Std. Error } \\
\text { Difference }\end{array}$} & \multicolumn{2}{|c|}{$\begin{array}{l}95 \% \text { Confidence Interval } \\
\text { of the Difference }\end{array}$} \\
\hline & & & & & & & & & Lower & Upper \\
\hline \multirow[t]{2}{*}{ Posttest } & $\begin{array}{l}\text { Equal variances } \\
\text { assumed }\end{array}$ & 2.459 & .122 & 14.21 & 58 & .000 & 6.73 & .473 & 5.78 & 7.68 \\
\hline & $\begin{array}{l}\text { Equal variances } \\
\text { not assumed }\end{array}$ & & & 14.21 & 53.53 & .000 & 6.73 & .473 & 5.78 & 7.68 \\
\hline
\end{tabular}


Table 5, shows there was a statistically significant difference in post test scores for PHIT group and ILIT group. This is so because the $p$ value was less than the specified level of significance $(.028<.05)$. The conclusion to be drawn from this part would be that the two groups were at roughly the same level of writing proficiency prior to the experiment, but after the experiment, the PHIT learners succeeded to show a significantly better performance. The difference between the pretest scores of the PHIT and ILIT was very small, but their difference on the post-test was considerable. This led to the rejection of the first research hypothesis.

TABLE 6.

PAIRED SAMPLES STATISTICS (PRE AND POST-TESTS OF BOTH GROUPS)

\begin{tabular}{|c|c|c|c|c|c|}
\hline \multirow[t]{2}{*}{ Pair 1} & PHIT Group Posttest & 25.4667 & 30 & 1.54771 & .28257 \\
\hline & PHIT Group Pretest & 18.0667 & 30 & 1.43679 & .26232 \\
\hline \multirow[t]{2}{*}{ Pair 2} & ILIT Group Posttest & 18.7333 & 30 & 2.08332 & .38036 \\
\hline & ILIT Group Pretest & 17.5333 & 30 & 1.71672 & .31343 \\
\hline
\end{tabular}

Table 6 shows the descriptive statistics on the pre-test and post-test of both groups. The results show that there is a difference between the mean of pre-test (9.4000) and post-test (18.2667) of the PHIT group. The students of PHIT group had development on their post-test in comparison to their pre-test. Moreover, the results show that the means of the ILIT group on the pre-test and post-test are 17.5333 and 18.7333 respectively which means that the control group had a little improvement on their post-test.

TABLE 7.

PAIRED SAMPLE T-TEST FOR BOTH GROUPS

\begin{tabular}{|c|c|c|c|c|c|c|c|c|c|}
\hline \multicolumn{10}{|c|}{ PAIRED SAMPLE T-IEST FUR BUTH GRUUPS } \\
\hline & & \multicolumn{5}{|c|}{ Paired Differences } & \multirow[t]{3}{*}{$\mathrm{t}$} & \multirow[t]{3}{*}{ df } & \multirow{3}{*}{$\begin{array}{l}\text { Sig. (2- } \\
\text { tailed) }\end{array}$} \\
\hline & & \multirow[t]{2}{*}{ Mean } & \multirow[t]{2}{*}{$\begin{array}{l}\text { Std. } \\
\text { Deviation }\end{array}$} & \multirow[t]{2}{*}{$\begin{array}{l}\text { Std. Error } \\
\text { Mean }\end{array}$} & \multicolumn{2}{|c|}{$\begin{array}{l}95 \% \text { Confidence Interval of } \\
\text { the Difference }\end{array}$} & & & \\
\hline & & & & & Lower & Upper & & & \\
\hline Pair 1 & $\begin{array}{l}\text { PHIT Group } \\
\text { Posttest - PHIT } \\
\text { Group Pretest }\end{array}$ & 7.40000 & 1.49943 & .27376 & 6.84011 & 7.95989 & 27.031 & 29 & .000 \\
\hline Pair 2 & $\begin{array}{l}\text { ILIT Group } \\
\text { Posttest - ILIT } \\
\text { Group Pretest }\end{array}$ & 1.20000 & 2.00688 & .36641 & .45062 & 1.94938 & 3.275 & 29 & .003 \\
\hline
\end{tabular}

Table 7 depicts that Sig is .000 which is less than 0.05 , therefore; the difference between the pre-test and post-test of the PHIT group is significant at $(p<0.05)$. Moreover, Sig is .005 which is less than 0.05 ; therefore, there is a difference between the pre-test and post-test of the ILIT group $(p<0.05)$, but it is not of great importance.

\section{DisCUSSION AND CONCLUSION}

Regarding the first research question of this study, after collecting the data, the researcher used paired samples t-test and independent samples t-test to analyze them in order to find out the effectiveness of topic interest on the students' writing skill. The findings showed that topic interest has a significant positive effect on students' writing skill. The results statistically revealed that PHIT group significantly did better than the ILIT group $(p<.05)$. Therefore, the null hypothesis of the study "Topic interest does not significantly impact L2 writing skill” was rejected.

For the second research question, these results tell us that as pre-intermediate in PHIT group performed better on post-test than intermediate ones in ILIT group, so L2 proficiency did not significantly impact L2 writing skill.

The outcomes of the current study are consistent with the results of some of the studies reported in the review of literature. However, some of the findings seem not to be in line with the results of other scholars.

The results of the present study in one case seem to be inconsistent with those of the other scholars. That 12 proficiency did not have any significant effect on the writing skill partially contradicts the findings of Lee and Pulido (2016) who reported a significant effect of L2 proficiency on the writing skill.

Generally, the discoveries of the current study are in line with previous qualitative and quantitative studies demonstrating that enriching the EFL students with academic choices would help them in their conflict for EFL learning. Specifically, the results confirmed the idea that providing EFL learners at all levels with self-selected topics would result in a satisfactory performance on EFL writing.

Outcomes of the present study put more stress on the importance of interest in writing skill. This is in line with previous studies that claim teaching methods are not provided in accordance with the necessities of students so that these methods do not open up superior opportunity for students to develop their writing skill. Hence, it is crucial to expand more interesting topics to assist learners with their writing improvement. The major limitation of this research was the number of respondents. This study, with regard to the lack of time, could not involve a large number of participants. It may impact the generalizability of the findings.

The present study checked the impact of topic interest and 12 proficiency on writing improvement. It is proposed for further studies to precisely scrutinize the usefulness of topic interest on other language skills such as speaking, listening, and reading. 


\section{REFERENCES}

[1] Ainley, M., Hidi, S., \& Berndorff, D. (2002). Interest, learning, and the psychological processes that mediate their relationship. Journal of Educational Psychology, 94, 545-561.

[2] Ainley, M., Hillman, K., \& Hidi, S. (2002). Gender and interest processes in response to literary texts: Situational and individual interest. Learning and Instruction, 12, 411-428.

[3] Brantmeier, C. (2003). Does gender make a difference? Passage content and comprehension in second language reading. Reading in a Foreign Language, 15, 1-27.

[4] Bray, G.B., \& Barron, S. (2004). Assessing reading comprehension: The effects of text-based interest, gender, and ability. Educational Assessment, 9, 107-128.

[5] Bristow Evans, M. (2018). The integration of reading, writing, speaking, and listening skills in the middle school social studies classroom. Retrieved from https://digitalcommons.usu.edu/cgi/viewcontent.cgi?article=8259\&context=etd.

[6] Carrell, C.L., \& Wise, T.E. (1998). The relationship between prior knowledge and topic interest on second language reading. Studies in Second Language Acquisition, 20, 285-309.

[7] Ebrahimi, S., \& Javanbakht, Z. (2015). The effect of topic interest on Iranian EFL learners' reading comprehension ability. Journal of Applied Linguistics and Language Research 2(6), 80-86.

[8] Erçetin, G. (2010). Effects of topic interest and prior knowledge on text recall and annotation use in reading a hypermedia text in the L2. ReCALL, 22, 228-246.

[9] Grice, H.P. (1975). Logic and Conversation. In Martinich, A.P. (ed.). Philosophy of language. (pp. 165-175) New York, NY: Oxford University Press.

[10] Joh, J. (2006). What happens when L2 readers recall? Language Research, 42, 205-238.

[11] Lee, S., \& Pulido, D. (2016). The impact of topic interest, L2 proficiency, and gender on EFL incidental vocabulary acquisiti on through reading. Language Teaching Research. 22(1), 118-135

[12] LeLoup, J.W. (1993). The effect of interest level in selected text topics on second language reading comprehension. Unpublished doctoral dissertation, The Ohio State University, Columbus, OH, USA.

[13] Popham, W. J. (2005). Students' attitudes count. Educational Leadership, 62(5), 84-85.

[14] Ramshaw, G. (2010). Expert group report for award seeking admission to the UCAS tariff. Retrieved from https://www.ucas.com/sites/default/files/cambridge-esol-report.pdf.

[15] Royster, D. C., Kimharris, M., \& Schoeps, N. (1999). Dispositions of college mathematics students. International Journal of Mathematical Education in Science and Technology, 30, 317-333.

[16] Stevens, K. (1980). The effect of topic interest on the reading comprehension of higher ability students. Journal of Educational Research, 73, 365-368.

[17] Walker, S.M., Noland, R.G., \& Greenshields, C.M. (1979). The effect of high and low interest content on instructional levels in informal reading inventories. Reading Improvement, 16, 297-300.

[18] Young, D.J., \& Oxford, R. (1997). A gender-related analysis of strategies used to process written input in the native language and foreign language. Applied Language Learning, 8, 43-73.

Rasool Mirshekaran was born in 1991. He is currently an M.A student in TEFL at Chabahar Maritime University. He completed his bachelor's degree in English translation at Zand institute of Higher Education in Shiraz. His research interests include: technology in Teaching, language testing, Applied linguistics and sociolinguistics

Ehsan Namaziandost was born in Shiraz Province of Iran in 1985. He holds an MA degree in TEFL from Islamic Azad University of Ahvaz. Now, he is a Ph.D. student in TEFL at Islamic Azad University of Shahr-e Kord. His main interests of research are second language acquisition, EFL teaching, teaching and testing, teaching speaking, communication and language learning strategies. His research papers and articles have been published by different international journals.

Mojtaba Nazari was born in 1990. He is currently a master student in Teaching Persian to the non-Persian speakers at Shiraz University. He completed his bachelor's degree in English language and literature at Zand institute of Higher Education in Shiraz 2014.his area of research includes: Cultural evaluation of language textbooks, material developments 